\title{
PENTINGNYA PROFESIONALISME GURU DALAM PENDIDIKAN
}

\author{
*Syamsiah Nur ${ }^{1)}$ Mardiah, mardiah ${ }^{2)}$ \\ 1) Email: syamsiah.nur@stai-tbh.ac.id \\ ${ }^{2)}$ Email: mardiah@stai-tbh.ac.id \\ 1)2) STAI Auliaurrasyidin Tembilahan, Indragiri Hilir, Riau, Indonesia
}

\begin{abstract}
This study aimed to determine the importance of teacher professionalism in education. This study used descriptive qualitative research by describing the importance of professionalism for teachers. One of the most important factors in realizing the goals of education in Indonesia is the teacher's professionalism in the implementation of teaching and learning activities. The problem today is that many students are confused after completing their education. Where to go? What kind of work? What student's want with this certificate? More unemployment means education has a lack of quality. Educational institutions that were supposed to produce knowledgeable students were lost due to the unprofessional quality teachers. The results showed that professionalism is very important for teachers and is a demand in a profession so that there are laws that regulate the obligations of professional teachers, there are several assumptions that underlie the needs for teacher professionalism in education, and there are some special requirements that must be met by professionalism teachers in education.
\end{abstract}

Keywords: Teacher Professionalism, Education

\begin{abstract}
Abstrak
Penelitian ini bertujuan untuk mengetahui pentingnya profesionalisme guru dalam pendidikan. Penelitian ini menggunakan penelitian kualitatif dengan jenis penelitian deskripsi, dengan menggambarkan pentingnya profesionalisme bagi guru. Salah satu faktor yang paling penting dalam mewujudkan tujuan pendidikan di Indonesia adalah profesionalisme guru dalam pelaksanaan kegiatan belajar mengajar di sekolah. Permasalahan dewasa ini banyak anak didik yang bingung setelah menyelesaikan pendidikannya. Harus ke mana? Kerja apa? Mau diapakan ijazah ini? Semakin banyak pengangguran berarti semakin banyak pula pendidikan yang menampakkan kurangnya kualitas. Lembaga pendidikan yang seharusnya mencetak anak didik siap pakai dan berilmu menjadi hilang, disebabkan kualitas guru yang tidak profesional. Hasil penelitian menunjukkan profesionalisme sangat penting bagi guru dan menjadi tuntutan dalam sebuah profesi sehingga ada undang-undang yang mengatur tentang kewajiban bagi guru profesional, ada beberapa asumsi yang melandasi perlunya profesionalisme guru dalam pendidikan dan ada beberapa persyaratan khusus yang harus dipenuhi guru profesionalisme dalam pendidikan.
\end{abstract}

Kata Kunci: Profesionalisme Guru, Pendidikan

\section{Cara Mensitasi Artikel:}

Nur, S., \& Mardiah, M. (2020). Pentingnya profesionalisme guru dalam pendidikan. Al-Liqo: Jurnal Pendidikan Islam, 5(02), 215-228. https://doi.org/10.46963/alliqo.v5i02.245

\begin{tabular}{|c|c|}
\hline $\begin{array}{c}\text { *Corresponding author: } \\
\text { Syamsiah.nur@stai-tbh.ac.id }\end{array}$ & $\begin{array}{lr} & \text { Histori Artikel: } \\
\text { Diterima } & : 04 / 12 / 2020 \\
\text { Direvisi } & :- \\
\text { Diterbitkan } & : 28 / 12 / 2020\end{array}$ \\
\hline
\end{tabular}

DOI: https://doi.org/10.46963/alliqo.v5i02.245 


\section{PENDAHULUAN}

Salah satu komponen suatu sekolah sebagai sebuah sistem adalah guru. Guru merupakan pendidik profesional dengan tugas utama mendidik, mengajar, membimbing, mengarahkan, melatih, menilai, dan mengevaluasi peserta didik pada pendidikan anak usia dini jalur pendidikan formal, pendidikan dasar, dan pendidikan menengah. ‘

Guru memegang peran yang sangat penting dalam proses pencapaian tujuan pendidikan. Untuk itu, diperlukan guru yang kreatif dan menyenangkan sehingga mampu menciptakan iklim pembelajaran yang kondusif, suasana pembelajaran yang menantang dan mampu membelajarkan dengan menyenangkan. Hal ini penting, terutama dalam setiap pembelajaran guru memiliki peranan yang sangat sentral, baik sebagai perencana, pelaksana maupun evaluator pembelajaran. (A. Marjuni, 2020: 17).

Guru mempunyai fungsi, dan kedudukan yang sangat strategis dalam pembangunan nasional. Kedudukan guru sebagai tenaga profesional bertujuan untuk melaksanakan sistem pendidikan nasional dan mewujudkan tujuan pendidikan nasional, yaitu berkembangnya potensi peserta didik agar menjadi manusia yang beriman dan bertakwa kepada Tuhan Yang Maha Esa, berakhlak mulia, sehat, berilmu, cakap, kreatif, mandiri, serta menjadi warga negara yang demokratis dan bertanggung jawab.

Guru harus mampu menciptakan situasi kelas yang tenang, bersih, tidak stres, dan sangat mendukung untuk pelaksanaan proses pembelajaran. (Dede Rosyada, 2017: 7). Guru harus memiliki keahlian dan kesadarannya tentang tugas yang harus dijalankannya. Hal tersebut dikenal dengan istilah profesionalisme. Profesionalisme merupakan salah satu hal yang harus dimiliki guru dalam penyelenggaraan perlindungan anak.

Guru yang profesionalisme adalah guru yang ahli dan sesuai dibidangnya dan memiliki kompetensi pedagogi, sosial, kepribadian dan profesionalisme. Guru yang profesional akan menyadari betapa pentingnya pemenuhan hak-hak anak 
yang harus dilindungi agar tumbuh kembang anak dapat distimulasi secara optimal. (Desmawati Roza dkk, 2020: 268).

Profesionalisme pendidikan pada umumnya dan profesionalisme pendidikan Islam pada khususnya merupakan tanggung jawab kita bersama. Saat ini dengan begitu pesatnya perkembangan dan tuntutan era global, sekolah maupun madrasah kita semakin dituntut untuk meningkatkan profesionalitasnya dalam rangka mewujudkan daya saing dalam arus globlal. Setiap sekolah atau madrasah dituntut untuk mampu menghadapi berbagai permasalahan psikologis dan pedagogis yang selalu akan muncul. (Sumarno, 2019: 60).

\section{METODE}

Jenis penelitian yang digunakan adalah library research dengan analisis deskriptif yaitu dengan menganalisis dan menggambarkan secara umum pentingnya profesionalisme guru di sekolah. Teknik pengumpulan datanya dari beberapa buku-buku dan jurnal yang ada kaitannya dengan masalah pentingnya profesionalisme guru dalam pendidikan, baik tentang pengertian profesionalisme guru, persyaratan menjadi guru yang profesional dan asumsi yang melandasi perlunya profesionalisme guru dalam pendidikan di sekolah.

1. Sumber Data

Kajian yang penulis gunakan adalah penelitian perpustakaan murni, penulis akan menggunakan dua sumber, yaitu:

a. Sumber Primer

Sumber data yang bersifat primer adalah buku rujukan awal dan utama dalam penelitian, sumber primer yang penulis gunakan adalah :

1) Arka, I. W. (2020). Kompetensi Pendidik Perspektif Membangun Profesionalisme Guru. Widyacarya: Jurnal Pendidikan, Agama dan Budaya, Volume 4 Nomor. 1 Maret.

2) Husaini, Rusdiana. (2018). Pembinaan Profesional Guru. Jurnal Tarbiyah Islamiyah: Jurnal Ilmiah Pendidikan Agama Islam. UIN Antasari-Banjar Masin Volume 8 Nomor 2 Juli-Desember. Diakses pada 2 Oktober 2020 jam 1.04 PM. 
3) Nurdin, Syafrudin dan M. Basyirudin Usman. (2002). Guru Profesional dan Implementasi Kurikulum. Jakarta: Ciputat Pers.

4) Rusman. (2014). Model-Model Pembelajaran (Mengembangkan Profesionalisme Guru. Jakarta: Raja Grafindo Persada.

5) Roza, D., Nurhafizah, N., \& Yaswinda, Y. (2019). Urgensi profesionalisme guru pendidikan anak usia dini dalam penyelenggaraan perlindungan anak. Jurnal Obsesi: Jurnal Pendidikan Anak Usia Dini, Volume 4 Nomor 1.

6) Rosyada, Dede. (2017). Madrasah dan Profesionalisme Guru dalam Arus Dinamika Pendidikan Islam di Era Otonomi Daerah. Kencana.

7) Samani, Mukhlas dkk. (2003). Pembinaan Profesi Guru. Jakarta: Depdiknas.

8) Usman, Moh. Uzer. (2009). Menjadi Guru Profesional. Bandung, Remaja Rosdakarya.

b. Sumber Sekunder

Sumber sekunder adalah hasil pengumpulan yang dilakukan oleh orang lain dengan maksud tertentu dan mempunyai kategori atau klasifikasi menurut keperluan masing-masing dan kegunaan bagi peneliti masingmasing, S. Nasotion ( 2002: 143)

Dalam hal ini Sumber data yang bersifat sekunder adalah buku rujukan pendukung dalam penelitian, sumber sekunder yang penulis gunakan adalah:

1) Budianto, A. A. (2020). Persepsi Mahasiswa Bimbingan Dan Konseling Terhadap Pentingnya Profesionalisme Guru Bimbingan Dan Konseling Di Sekolah. Edu Consilium: Jurnal Bimbingan dan Konseling Pendidikan Islam, Volume 1 Nomor. 1.

2) Euis Karwati dan Donni Juni Priansa, (2015). Manajemen Kelas Classroom Management Guru Profesional yang Inspiratif, Kreatif, Menyenangkan, dan Berprestasi, Bandung: Alfabeta.

3) Marjuni, A., \& Suban, A. (2020). Profil Guru Harapan Masa Depan. Al asma: Journal of Islamic Education, Volume 2 Nomor.1. 
4) U, M. Shabir. (2015). Kedudukan Guru Sebagai Pendidik: (Tugas Dan Tanggung Jawab, Hak Dan Kewajiban, Dan Kompetensi Guru). Jurnal Auladuna, Volume 2 Nomor 2 Desember. Fakultas Tarbiyah dan Keguruan UIN Alauddin Makassar. Email: mshabiru@gmail.com. Diakses pada 4 Oktober 2020 pukul 11.27 AM.

5) Yamin, Martinis. (2006). Sertifikasi Profesi Keguruan Di Indonesia. Jakarta: Gaung Persada Press.

2. Teknik Pengumpulan Data

Teknik pengumpulan data adalah cara-cara yang digunakan oleh peneliti untuk mengumpulkan data. Pengumpulan data dalam penelitian ini adalah dengan cara dokumentasi. Dokumentasi adalah "ditujukan untuk memperoleh data langsung dari tempat penelitian, meliputi buku-buku yang relevan, peraturan-peraturan, laporan kegiatan, foto-foto, film, dokumenter, data yang relevan penelitian, Riduwan (2013: 24).

3. Teknik Analisa Data

Teknik analisa data adalah cara penghitungan untuk menjawab rumusan masalah dan pengujian hipotesis yang diajukan, Riduan (2015: 12). Hipotesis adalah jawaban sementara yang harus di uji kebenarannya. Namun, penelitian yang penulis gunakan dengan kajian pustaka (library research) ini, maka penulis menggunakan teknik analisa data kajian isi (content analysis).

Kajian ini adalah kajian yang menanfaatkan buku atau dokumen untuk menarik kesimpulan, baik kajian isi yang bersifat deduktif maupun kajian isi yang bersifat induktif, Lexy J. Moleong (2013: 220). Pada kajian ini peneliti terlebih dahulu mengadakan survei data untuk memperoleh informasi dari penelitian terdahulu terhadap pengerjaan tanpa memedulikan apakah data itu primer atau sekunder, di lapangan atau di laboratorium. Kemudian, menelusuri literatur yang ada serta menelaahnya secara tekun. Setelah itu, peneliti mengungkapkan buah pikiran secara kritis dan analitis, Moh. Nazir (2005: 93). 


\section{HASIL DAN PEMBAHASAN}

\section{A. Profesionalisme Guru}

Profesi adalah suatu pekerjaan dalam melaksanakan tugasnya memerlukan/ menuntut keahlian (expertise), menggunakan teknik-teknik ilmiah, serta dedikasi tinggi. Keahlian diperoleh dari lembaga pendidikan yang khusus diperuntukkan untuk itu dengan kurikulum yang dapat dipertanggungjawabkan. Kata profesi diartikan sebagai bidang pekerjaan yang dilandasi pendidikan keahlian (keterampilan, kejuruan, dan sebagainya) tertentu. Di dalam profesi dituntut adanya keahlian dan etika khusus serta standar layanan. Merujuk pada pengertian ini bahwa profesi hanya dapat dilakukan oleh orang-orang secara khusus dipersiapkan untuk itu. Dengan kata lain profesi bukan pekerjaan yang dilakukan oleh mereka yang karena tidak memperoleh pekerjaan lain. Suatu profesi memerlukan kompetensi khusus yaitu kemampuan dasar berupa keterampilan menjalankan rutinitas sesuai dengan petunjuk, aturan, dan prosedur teknis.

Profesionalisme adalah suatu pandangan terhadap keahlian tertentu yang diperlukan dalam pekerjaan tertentu, yang mana keahlian itu hanya diperoleh melalui pendidikan khusus atau latihan khusus. (Rusman, 2014 :18). Pendidikan dan pelatihan merupakan upaya untuk mengembangkan sumber daya guru-guru, terutama untuk peningkatan profesionalisme yang berkaitan dengan keterampilan. Guru profesional selalu mengikuti kursus-kursus, workshop, seminar, dalam berbagai kegiatan lainnya.

Profesionalisme sangat penting terhadap sosok yang berprofesi sebagai seorang guru dan menjadi tuntutan dalam sebuah profesi. Profesionalisme membutuhkan sebuah keterampilan dan keahlian yang harus dimiliki seorang guru dalam pekerjaannya. Keterampilan dan keahlian dalam suatu bidang tertentu dan juga tentunya memerlukan waktu untuk mempelajarinya. Kemampuan akademik menjadi syarat dalam profesi seorang guru, supaya tidak terjadi mal-praktek dalam pelaksanaannya. (Syafrudin Nurdin dan M. Basyirudin Usman, 2002: 14). 
Guru profesional haruslah memiliki keahlian, keterampilan, dan kemampuan sebagaimana filosofi Ki Hajar Dewantara sebagai bapak pendidikan kita yang mengatakan dengan semboyan "Tut Wuri Handayani, Ing Ngarso sung Tulodo, Ing Madyo Mangun Karso", oleh karena itu guru profesional tidak cukup hanya menguasai pelajaran akan tetapi juga harus mengayomi anak didik menjadi teladan serta selalu memotivasi anak didik untuk lebih baik dan maju. Guru Profesional harus rajin dan giat membaca literatur-literatur untuk menambah wawasan pengetahuannya dengan tidak merasa rugi membeli buku-buku yang berkaitan dengan pengetahuan yang digelutinya. (Zakiyah Daradjat, 2006: 40-42).

Menurut Surya dalam Euis Karwati dan Donni Juni Priansa menyatakan bahwa profesionalisme merupakan istilah yang mengacu pada sikap mental dalam bentuk komitmen dari para anggota suatu profesi untuk senantiasa mewujudkan dan meningkatkan kualitas profesionalnya. (Euis Karwati dan Donni Juni Priansa, 2015: 70). Sikap mental yang harus dimiliki guru profesional diantaranya sikap kemanusiaan, kepribadian, kesabaran, kedisiplinan, dan kerendahhatian.

Guru profesional akan bekerja hanya semata-mata memberikan pelayanan kemanusiaan dari pada usaha untuk kepentingan pribadi. Dalam menumbuhkan sikap mental, guru harus lebih bijak dan hati-hati dalam pendekatan kepada anak didik, untuk itu dibutuhkan kecakapan mengarahkan motivasi dan berpikir.

Menurut Kunandar profesionalisme guru merupakan kondisi, arah, nilai, tujuan, dan kualitas suatu keahlian dan kewenangan dalam bidang pendidikan dan pengajaran yang berkaitan dengan pekerjaan seseorang yang menjadi mata pencaharian. (Kunandar, 46). Pekerjaan yang bersifat profesional adalah pekerjaan yang hanya dapat dilakukan oleh orang-orang yang khusus sudah dipersiapkan seperti halnya seorang guru. Untuk menjadi seorang guru yang profesional, haruslah memiliki kemampuan dan keahlian dalam bidang keguruan, sehingga guru tersebut mampu melakukan tugas dan fungsinya sebagai guru secara maksimal. 


\section{B. Kewajiban Guru Profesional}

Guru profesional dituntut untuk memiliki kompetensi-kompetensi khusus. Guru profesional juga dituntut untuk melaksanakan kewajibankewajiban yang dibebankan kepadanya. Menurut pasal 20 Undang-Undang Republik Indonesia Nomor 14 Tahun 2005 tentang Guru dan Dosen menyebutkan beberapa kewajiban yaitu:

1. Guru profesional merencanakan pembelajaran, melaksanakan proses pembelajaran yang berkualitas, serta menilai dan mengevaluasi hasil pembelajaran.

2. Guru profesional meningkatkan dan mengembangkan kualifikasi akademik dan kompetensi secara berkelanjutan sejalan dengan perkembangan ilmu pengetahuan, teknologi, dan seni.

3. Guru profesional bertindak objektif dan tidak diskriminatif atas dasar pertimbangan jenis kelamin, agama, suku, ras, dan kondisi fisik tertentu.

4. Guru profesional menjunjung tinggi peraturan perundang-undangan hukum, dan kode etik guru, serta nilai-nilai agama dan etika.

5. Guru profesional memelihara dan memupuk persatuan dan kesatuan bangsa. (M. Shabir U, 2015: 228-229).

Dengan melaksanakan kewajiban-kewajiban sebagaimana diamanatkan oleh undang-undang tersebut di atas, seorang guru akan tetap dapat eksis di tengah-tengah perkembangan ilmu pengetahuan dan teknologi yang semakin pesat. Demikian pula para peserta didik akan semakin hormat kepadanya karena mereka melihat guru mereka sebagai sosok yang senantiasa dapat ditiru dan digugu.

\section{Asumsi Yang Melandasi Perlunya Profesionalisme Guru Dalam Pendidikan}

Berkenaan dengan pentingnya profesionalisme guru dalam pendidikan Sinusi mengutarakan enam asumsi yang melandasi perlunya profesional-isasi dalam pendidikan yaitu: 
1. Subjek pendidikan.

Manusia yang memiliki kemauan, pengetahuan, emosi, dan perasaan dan dapat dikembangkan sesuai dengan potensinya; sementara itu pendidikan dilandasi oleh nilai-nilai kemanusian yang menghargai martabat manusia

2. Pendidikan dilakukan secara intensional.

Secara sadar bertujuan, maka pendidikan menjadi normatif yang diikat oleh norma-norma dan nilai-nilai yang baik secara universal, nasional maupun lokal, yang merupakan acuan para pendidik, peserta didik dan mengelola pendidikan.

3. Teori-teori pendidikan merupakan jawaban kerangka hipotesis dalam menjawab permasalahan pendidikan.

4. Pendidikan bertolak dari asumsi pokok tentang manusia. (I Wayan Arka, 2020: 58).

Manusia mempunyai potensi yang baik untuk berkembang. Oleh sebab itu, pendidikan itu adalah usaha untuk mengembangkan potensi unggul tersebut

a. Inti pendidikan terjadi dalam prosesnya.

Situasi di mana terjadi dialog antara peserta didik dengan pendidik yang memungkinkan peserta didik tumbuh ke arah yang dikehendaki oleh pendidik agar selaras dengan nilai-nilai yang dijunjung tinggi masyarakat

b. Sering terjadinya dilema antara tujuan utama pendidikan.

Menjadikan manusia sebagai manusia yang baik (dimensi intrinsik) dengan misi instrumental, yakni merupakan alat untuk perubahan atau mencapai sesuatu. (Rusman, 2014, 20). 


\section{Persyaratan Profesionalisme Guru Dalam Pendidikan}

Pentingnya profesionalisme guru dalam pendidikan Moh. Uzer Usman mengutarakan persyaratan khusus antara lain:

1. Guru profesional perlu adanya keterampilan yang berasaskan konsep dan teori ilmu pengetahuan yang mendalam.

2. Guru profesional ditekankan memiliki suatu keahlian dalam bidang tertentu yang sesuai dengan profesinya.

3. Guru profesional dituntut adanya pendidikan keguruan yang memadai.

4. Guru profesional hendaklah peka terhadap dampak kemasyarakatan dari pekerjaan yang dilaksanakannya.

5. Guru profesional haruslah mempunyai perkembangan yang sejalan dengan dinamika kehidupan.

6. Guru profesional harus memiliki kode etik sebagai acuan dalam melaksanakan tugas dan fungsinya.

7. Guru profesional harus memiliki objek layanan yang tetap seperti dokter dengan pasiennya.

8. Guru profesional itu diakui oleh masyarakat karena memang diperlukan jasanya di masyarakat. (Moh. Uzer Usman, 2009: 15).

Menurut Martinis Yamin menjadi seorang guru yang profesional bukanlah hal yang gampang, tidak bisa hanya bermodalkan penguasaan materi dan menyampaikannya kepada siswa. Dua hal tersebut belumlah cukup, sehingga belum bisa dikategorikan guru profesional. Karena guru yang profesional harus memiliki beberapa persyaratan diantaranya:

1. Guru profesional harus memiliki berbagai keterampilan.

2. Guru profesional harus memiliki kemampuan khusus.

3. Guru profesional harus mencintai pekerjaannya.

4. Guru profesional harus menjaga kode etik guru. (Martinis Yamin, 2006: 23).

Syarat-syarat suatu pekerjaan disebut profesional sebagai berikut:

1. Guru profesional bekerja atas dasar panggilan hidup yang dilakukan dengan sepenuh hati serta memerlukan jangka waktu yang lama.

2. Guru profesional telah memiliki pengetahuan dan keterampilan khusus. 
3. Guru profesional bekerja berdasarkan teori, prinsip, prosedur, dan anggapan-anggapan dasar yang sudah baku sebagai pedoman dalam mengajar.

4. Guru profesional bekerja sebagai pengabdian kepada masyarakat, bukan mencari keuntungan finansial.

5. Guru profesional memiliki kecakapan diagnostik dan kompetensi aplikatif dalam melayani siswa.

6. Guru profesional dilakukan secara otonom yang bisa diuji rekan-rekan seprofesinya.

7. Guru profesional mempunyai kode etik yang dijunjung tinggi oleh masyarakat.

8. Guru profesional bekerja untuk melayani mereka yang membutuhkan. (Made Pidarta, 2000: 266).

Menurut Mukhlas Samani dkk syarat-syarat profesi sebagai berikut:

1. Guru profesional memiliki fungsi yang signifikan dalam kehidupan masyarakat di mana guru itu berada.

2. Guru profesional memerlukan keahlian dan keterampilan tertentu yang tidak dapat dijangkau oleh masyarakat awam pada umumnya.

3. Guru profesional mempunyai keahlian yang diperlukan di masyarakat dan dikembangkan berdasarkan disiplin ilmu yang jelas dan sistematik.

4. Guru profesional memerlukan pendidikan dan pelatihan yang sangat panjang, sebelum seseorang mampu memangku profesi tersebut.

5. Guru profesional memiliki otonomi dalam membuat keputusan yang terkait dengan ruang lingkup tugasnya.

6. Guru Profesional memiliki kode etik jabatan yang menjelaskan bagaimana profesi itu harus dilaksanakan oleh orang-orang yang memegangnya.

7. Guru profesional memiliki organisasi profesi yang merupakan tempat pemegang profesi berasosiasi dan mengembangkan profesi tersebut. (Mukhlas Samani dkk, 2003: 3-4).

Rusdiana Husaini memaparkan yang dikutip dalam Saipurrahman bahwa persyaratan profesi sebagai berikut: 
1. Menjadi guru profesional itu adalah pilihan terhadap jabatan yang mana pilihan itu didasari oleh motivasi yang kuat dan merupakan panggilan hidup orang yang bersangkutan.

2. Guru profesional telah memiliki ilmu dan keterampilan khusus yang bersifat dinamis dan terus berkembang.

3. Guru profesional diperoleh melalui studi dalam jangka waktu yang lama.

4. Guru profesional mempunyai otonomi dalam bertindak ketika melayani anak didik.

5. Guru profesional mengabdi kepada masyarakat atau berorientasi kepada layanan sosial, bukan untuk mendapatkan keuntungan finansial semata.

6. Guru profesional tidak mengadvertensikan keahliannya untuk mendapatkan anak didik.

7. Guru profesional harus menjadi anggota dalam organisasi profesi.

8. Dalam organisasi profesi tersebut menentukan persyaratan penerimaan anggota, membina profesi anggota, mengawasi perilaku anggota, memberi sanksi, dan memperjuangkan kesejahteraan anggota.

9. Guru profesional memiliki kode etik profesi.

10. Guru profesional mempunyai kekuatan dan status yang tinggi sebagai expert yang diakui oleh masyarakat.

11. Guru profesional berhak mendapatkan imbalan yang layak. (Rusdiana Husaini, 2018: 2).

\section{KESIMPULAN}

Pentingnya profesionalisme guru dalam pendidikan akan bermanfaat bagi masyarakat yang berharap para guru memiliki kualitas yang baik dan akan menumbuhkan motivasi masyarakat untuk percaya bahwa dunia pendidikan mampu memberikan pelayanan yang memuaskan. Menjadi guru yang profesional perlu dipenuhi dari semua syarat-syarat yang sudah dipaparkan oleh para ahli di atas, agar benar-benar menjadi guru profesional itu tidak mengecewakan orang lain dan memuaskan bagi diri guru yang profesional tersebut, bahwa dirinya 
benar-benar profesional atas usaha dan upaya sendiri memperjuangkannya. Hal ini bisa dicontoh bagi guru-guru yang belum mencapai predikat guru profesional.

\section{REFERENSI}

Arka, I. W. (2020). Kompetensi pendidik perspektif membangun profesionalisme guru. Widyacarya: Jurnal Pendidikan, Agama dan Budaya, 4(1). 55-62. https://jurnal.stahnmpukuturan.ac.id/index.php/widyacarya/article/view/5 52

Budianto, A. A. (2020). Persepsi mahasiswa bimbingan dan konseling terhadap pentingnya profesionalisme guru bimbingan dan konseling di sekolah. Edu Consilium: Jurnal Bimbingan dan Konseling Pendidikan Islam, 1(1). 1-12. http://dx.doi.org/10.1905/ec.v1i1.2930

Daradjat, Z. (2006). Ilmu Pendidikan Islam, Jakarta: Bumi Aksara.

Husaini, R. (2018). Pembinaan profesional guru. Jurnal Tarbiyah Islamiyah: Jurnal Ilmiah Pendidikan Agama Islam, 8(2). https://jurnal.uinantasari.ac.id/index.php/tiftk/article/view/2541

Karwati, E., \& Priansa, D. J. (2015). Manajemen Kelas Classroom Management Guru Profesional yang Inspiratif, Kreatif, Menyenangkan, dan Berprestasi, Bandung: Alfabeta.

Marjuni, A., \& Suban, A. (2020). Profil guru harapan masa depan. Al asma: Journal of Islamic Education, 2(1), 13-22, http://journal.uinalauddin.ac.id/index.php/alasma/article/view/13361

Nurdin, Syafrudin dan M. Basyirudin Usman. (2002). Guru Profesional dan Implementasi Kurikulum. Jakarta: Ciputat Pers.

Rosyada, Dede. (2017). Madrasah dan Profesionalisme Guru dalam Arus Dinamika Pendidikan Islam di Era Otonomi Daerah. Kencana.

Roza, D., Nurhafizah, N., \& Yaswinda, Y. (2019). Urgensi profesionalisme guru pendidikan anak usia dini dalam penyelenggaraan perlindungan anak. Jurnal Obsesi : Jurnal Pendidikan Anak Usia Dini, 4(1), 267-273. https://doi.org/10.31004/obsesi.v4i1.325

Rusman. (2014). Model-Model Pembelajaran (Mengembangkan Profesionalisme Guru). Jakarta: Raja Grafindo Persada.

Samani, Mukhlas dkk. (2003). Pembinaan Profesi Guru. Jakarta: Depdiknas.

Sumarno, S. (2019). Profesionalisme Dalam Pendidikan Islam. Al-Lubab: Jurnal Penelitian Pendidikan dan Keagamaan Islam,5(1), 45-62. http://ejournal.kopertais4.or.id/mataraman/index.php/allubab/article/view 13728 
U, M. Shabir. (2015). Kedudukan guru sebagai pendidik (Tugas dan tanggung jawab, hak dan kewajiban, dan kompetensi guru). Jurnal Auladuna, 2(2), 221 232. http://journal.uinalauddin.ac.id/index.php/auladuna/issue/view/158

Usman, Moh. Uzer. (2009). Menjadi Guru Profesional. Bandung, Remaja Rosdakarya.

Yamin, M. (2006). Sertifikasi profesi keguruan di Indonesia. Jakarta: Gaung Persada Press. 